\title{
Nanofluidi kao medij za prijenos topline
}

\author{
R. Blažic, F. Faraguna, E. Vidović* i A. Jukić \\ Fakultet kemijskog inženjerstva i tehnologije, Sveučilište u Zagrebu \\ Marulićev trg 19, 10000 Zagreb
}

\section{Sažetak}

U posljednjih 20 godina nanofluidi su privukli pažnju znanstvene zajednice te se broj radova na temu nanofluida tijekom godina znatno povećao. Povećana toplinska vodljivost fluida uslijed dodatka nanočestica osnovno je svojstvo koje je potaknulo intenzivno istraživanje nanofluida. S obzirom na to da u industriji uvijek postoji težnja poboljšanju učinkovitosti proizvodnih procesa, pa tako i procesa hlađenja procesnih struja, povećana toplinska vodljivost rashladnih fluida otvara mogućnosti za postizanje navedenog cilja. $U$ ovom radu dan je pregled metoda priprave nanofluida te opis parametara koji utječu na njihovu toplinsku vodljivost. Dan je i osvrt na modele kojima se opisuje toplinska vodljivost nanofluida te pregled mogućih mehanizama koji doprinose povećanju njihove toplinske vodljivosti.

\section{Ključne riječi}

Nanofluidi, toplinska vodljivost, stabilnost nanofluida

\section{Uvod}

Hlađenje procesnih struja i dijelova raznih uređaja prisutno je gotovo u svim granama industrije (petrokemijska, prerada nafte, tekstilna industrija) te ima vrlo važnu ulogu u procesu proizvodnje. Povećanje učinkovitosti procesa prijenosa topline doprinosi znatnim uštedama energije $u$ rashladnim sustavima u industriji, što kao posljedicu ima smanjenje dimenzija rashladnih sustava.

Konvencionalni pristup povećanju količine izmijenjene topline je kroz povećanje površine za izmjenu topline, što rezultira povećanjem dimenzija izmjenjivača topline. Međutim, navedeni pristup ne može se primijeniti kod pojedinih sustava gdje postoji ograničenje veličine dijelova uređaja, npr. kod hlađenja elektroničkih komponenata. ${ }^{1,2}$ Povećanje toplinske vodljivosti fluida značajno bi doprinijelo poboljšanju procesa izmjene topline. Poboljšanje toplinskih svojstava fluida pokušava se ostvariti dodatkom čvrstih čestica u konvencionalne rashladne fluide. Na taj način iskorištava se visoka toplinska vodljivost čvrstih čestica koje imaju za nekoliko redova veličine veću toplinsku vodljivost od kapljevina (tablica 1$){ }^{3}$

Istraživanjima je dokazano da suspenzije s čvrstim česticama mikrometarskih ili milimetarskih dimenzija pokazuju veću toplinsku vodljivost u odnosu na same bazne fluide. Značajan nedostatak takvih suspenzija je vrlo brza sedimentacija čestica zbog nemogućnosti stabilizacije suspenzije. ${ }^{4}$

Razvojem nanotehnologije i procesa proizvodnje nanočestica omogućena je priprava suspenzija s česticama nanometarskih dimenzija. Takve suspenzije nazivaju se nanofluidima. Dosadašnja istraživanja pokazuju da nanofluidi imaju veću toplinsku vodljivost u odnosu na konvencionalne rashladne fluide kod vrlo malih koncentracija suspendi-

\footnotetext{
*Autor za dopisivanje: prof. dr. sc. Elvira Vidović,

e-pošta: evidov@fkit.hr
}

Tablica 1 - Vrijednosti koeficijenta toplinske vodljivosti za odabrane krutine i kapljevine ${ }^{2}$

Table 1 - Thermal conductivity of some solids and liquids ${ }^{2}$

\begin{tabular}{c|c|c}
\hline \multirow{2}{*}{ metali } & Materijali & $\mathrm{k} / \mathrm{W} \mathrm{m}^{-1} \mathrm{~K}^{-1}$ \\
\cline { 2 - 3 } & $\mathrm{Fe}$ & 424 \\
\cline { 2 - 3 } & $\mathrm{Cu}$ & 80 \\
\hline \multirow{3}{*}{ metalni oksidi } & $\mathrm{Al}_{2} \mathrm{O}_{3}$ & 398 \\
\cline { 2 - 3 } & $\mathrm{Fe}_{2} \mathrm{O}_{3}$ & 40 \\
\cline { 2 - 3 } & $\mathrm{CuO}$ & 7 \\
\hline \multirow{3}{*}{ kapljevine } & voda & 77 \\
\cline { 2 - 3 } & etilen-glikol & 0,608 \\
\cline { 2 - 3 } & poli $(\alpha$-olefinsko $)$ ulje & 0,257 \\
\hline
\end{tabular}

ranih čestica. Uz toplinsku vodljivost za primjenu nanofluida važna su reološka svojstva i stabilnost suspenzije.

\section{Nanofluidi}

Nanofluidi su suspenzije koje sadrže čvrste čestice veličine $1-100 \mathrm{~nm}$ dispergirane u nekom baznom fluidu. ${ }^{4} \mathrm{Zbog}$ velikog omjera između površine i volumena čestice odnosno broja atoma na površini i unutrašnjosti čestice svojstva nanočestica i nanostrukturiranih materijala značajno se razlikuju od materijala makroskopskih dimenzija. ${ }^{5}$ Rezultati istraživanja nanofluida pokazuju da se toplinska vodljivost baznih fluida povećava s dodatkom nanočestica. Posebno se ističe povećanje toplinske vodljivosti poli( $\alpha$-olefinskog) ulja za $160 \%$ dodatkom 1 vol. \% višestjenčanih ugljikovih nanocijevi (MWCNT). lako se toplinska vodljivost navedenog nanofluida povećala s 0,1448 (bazni fluid) na 
0,3765 $\mathrm{W} \mathrm{m}^{-1} \mathrm{~K}^{-1}$, toplinska vodljivost nanofluida i dalje je niska u usporedbi s vodljivošću krutih čestica. ${ }^{6}$ Premda su postignuta ograničena poboljšanja, zbog povišene toplinske vodljivosti u odnosu na bazne fluide nanofluidi su potencijalni rashladni fluidi nove generacije.

Tablica 2 daje pregled često upotrebljavanih baznih fluida, nanočestica i površinski aktivnih tvari (PAT) za pripravu nanofluida koji se upotrebljavaju u rashladnim sustavima.

Tablica 2 - Prikaz komponenata nanofluida ${ }^{1,2,4,7}$

Table 2 - Components of nanofluids $1,2,4,7$

\begin{tabular}{|c|c|c|}
\hline \multirow{9}{*}{ 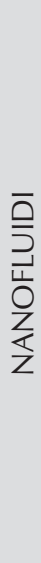 } & \multirow{3}{*}{ 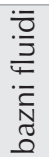 } & voda \\
\hline & & etilen-glikol \\
\hline & & ugljikovodično ulje \\
\hline & \multirow{3}{*}{ 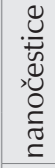 } & metali - Ag, Cu, Au, Fe \\
\hline & & metalni oksidi $-\mathrm{Al}_{2} \mathrm{O}_{3}, \mathrm{CuO}, \mathrm{TiO}_{2}, \mathrm{SiO}_{2}$ \\
\hline & & ugljikove nanocijevi (jednostjenčane i višestjenčane) \\
\hline & \multirow{3}{*}{ 衣 } & $\begin{array}{l}\text { natrijev dodecil-sulfat } \\
\text { (engl. sodium dodecyl sulphate-SDS) }\end{array}$ \\
\hline & & $\begin{array}{l}\text { natrijev dodecil benzensulfonat } \\
\text { (engl. sodium dodecylbenzenesulphonate-SDBS) }\end{array}$ \\
\hline & & $\begin{array}{l}\text { oleinska kiselina, tioglikolna kiselina, stearinska } \\
\text { kiselina }\end{array}$ \\
\hline
\end{tabular}

\section{Priprava nanofluida}

Izbor metode za pripravu nanofluida važan je za postizanje željenih svojstava nanofluida. Prilikom priprave nanofluida najvažnije je postići dobru dispergiranost nanočestica tj. spriječiti aglomeraciju čestica. Metode za pripravu nanofluida mogu se svrstati u dvije grupe: ${ }^{7,8,9}$ metode u jednom koraku i metode u dva koraka.

\subsection{Metode u jednom koraku}

Priprava nanofluida metodom u jednom koraku temelji se na istodobnoj sintezi nanočestica i njihovom dispergiranju u željeni bazni fluid. Pod tu metodu svrstava se kemijska sinteza, isparavanje materijala električnom iskrom ili grijaćim tijelom te kondenzacija materijala u baznom fluidu.

Kemijska sinteza nanočestica u baznom fluidu vrlo je pogodna metoda za pripravu nanofluida s metalnim česticama zbog jednostavnosti metode i dobre stabilnosti pripravljenog nanofluida. Metalne soli, prekursori za pripravu metalnih nanočestica, otope se u baznom fluidu te pogodnim sredstvom reduciraju u elementarno stanje. Odabirom pogodnih reakcijskih uvjeta i površinski aktivne tvari postiže se vrlo dobra kontrola veličine čestica. ${ }^{7,8} \mathrm{Na}$ nofluidi s uskom raspodjelom veličine čestica pogodni su za ispitivanje utjecaja veličine čestica na povećanje toplinske vodljivosti nanofluida.

Jedna od inovativnih metoda za pripravu nanofluida je izbijanje električnog luka na elektrodama uronjenim u dielektrični fluid kod koje se na elektrode, razmaknute nekoliko milimetara, narine električni napon. Prilikom probijanja dielektrika napon na elektrodama naglo pada, a poraste jakost električne struje te nastaje električni luk između elektroda. $U$ tom procesu razvija se visoka toplina te mali dio materijala ispari. Prilikom kontakta dielektričnog fluida i para metala dolazi do kondenzacije metalnih čestica. Dobrom kontrolom električnog napona, gustoće struje i temperature dielektričnog fluida mogu se pripremiti nanofluidi s veličinom čestica od 10 do 100 nm. ${ }^{10}$

\subsection{Metode u dva koraka}

Sinteza nanočestica i njihovo dispergiranje u bazni fluid dva su zasebna procesa. Prvi korak je proizvodnja nanočestica. To je dobro uhodan industrijski proces tako da su prašci nanočestica široko dostupni na tržištu. Upravo zbog velike dostupnosti nanoprašaka, nanofluidi se češće pripremaju metodom u dva koraka., 2,4,7,9 Neke od metoda priprave nanočestica su visokoenergetsko mljevenje, elektroeksplozija metalne žice, laserska ablacija, izbijanje u električnom luku, CVD postupak, itd. ${ }^{5}$ Drugi korak u pripremi nanofluida tom metodom je dispergiranje nanočestica u baznom fluidu. Da bi se razbili aglomerati nanočestica, upotrebljavaju se ultrazvučne kupelji ili sonde. Ponovna aglomeracija sprječava se dodatkom površinski aktivnih tvari ili nekih polimernih stabilizatora. ${ }^{4,7,8}$

Hong i sur. ${ }^{11}$ ispitivali su utjecaj ultrazvučnog miješanja na toplinsku vodljivost nanofluida na osnovi etilen-glikola s nanočesticama željeza. Duljim ultrazvučnim miješanjem veličina aglomerata nanočestica se smanjila, a toplinska vodljivost nanofluida je porasla. Kod nanofluida koji su ultrazvučno miješani 50 i 70 min zabilježeno je povećanje toplinske vodljivosti oko $18 \%$ kod 0,55 vol. \% nanočestica željeza u etilen-glikolu. Produljenjem miješanja iznad 50 min toplinska vodljivost se nije bitno promijenila što ukazuje da se veličina aglomerata nanočestica željeza ostala približno jednaka (slika 1).

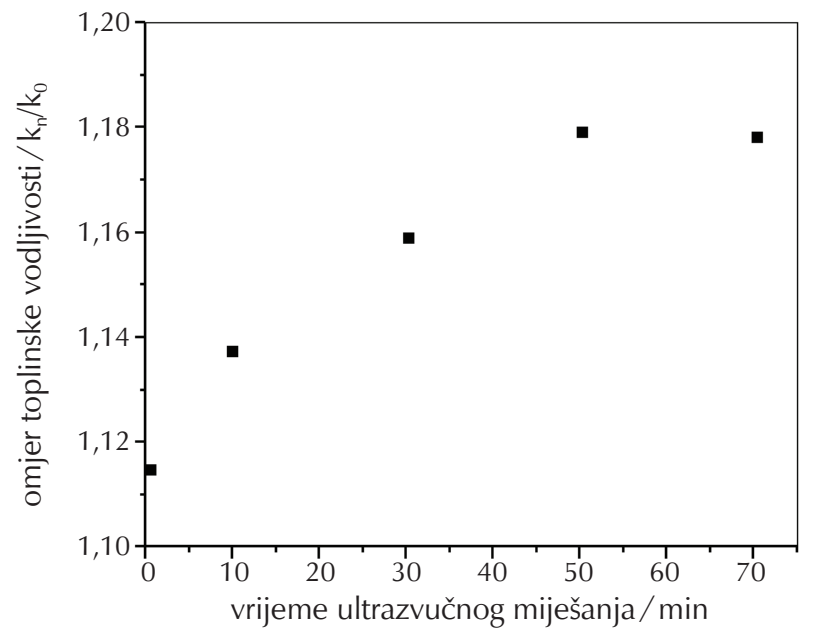

Slika 1 - Ovisnost toplinske vodljivosti nanofluida na osnovi etilen-glikola s 0,55 vol. \% Fe o vremenu ultrazvučnog miješanja ${ }^{11}$

Fig. 1 - Thermal conductivity of ethylene glycol based nanofluid with 0.55 vol\% Fe as a function of sonication time ${ }^{11}$ 
Sadri $i$ sur. ${ }^{12}$ istraživali su utjecaj ultrazvučnog miješanja na toplinsku vodljivost vodenih nanofluida s 0,24 vol. \% ugljikovih nanocijevi. Toplinska vodljivost nanofluida raste prilikom duljeg ultrazvučnog miješanja. Povećanje toplinske vodljivosti izraženije je kod uzoraka nanofluida koji su kraće ultrazvučno miješani, dok se toplinska vodljivost znatno manje povećava ultrazvučnim miješanjem duljim od 30 min (slika 2). Kako bi se jasnije istražio utjecaj ultrazvučnog miješanja na raspodjelu ugljikovih nanocijevi u nanofluidu, autori su određivali viskoznost nanofluida nakon ultrazvučnog miješanja. Nadalje, autori su snimili uzorke nanofluida TEM-om. Na temelju TEM mikrofotografija utvrđeno je da se veličina aglomerata MWCNT smanjuje s duljim ultrazvučnim miješanjem. Osim razbijanja aglomerata ultrazvučnim miješanjem dolazi do skraćivanja ugljikovih nanocijevi. Nanofluidi koji su ultrazvučno miješani 20 ili više minuta pokazivali su manju viskoznost u odnosu na nanofluid koji je ultrazvučno miješan 2 min.

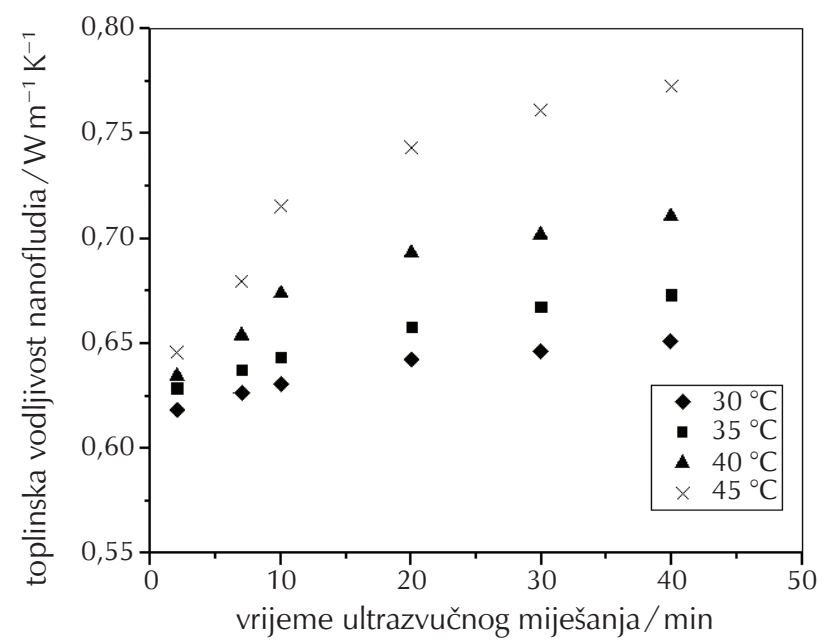

Slika 2 - Ovisnost toplinske vodljivosti vodenih nanofluida s 0,24 vol. \% MWCNT o vremenu ultrazvučnog miješanja ${ }^{14}$

Fig. 2 - Thermal conductivity of water based nanofluid with 0.24 vol\% MWCNT as a function of sonication time ${ }^{14}$

Ruan i Jacobi ${ }^{13}$ istraživali su utjecaj ultrazvučnog miješanja na toplinsku vodljivost nanofluida na osnovi etilen-glikola s MWCNT, pri čemu je kao stabilizacijsko sredstvo upotrijebljena arapska guma (engl. gum arabic, GA). Autori su proveli istraživanje u rasponu od 0 do 1350 min ultrazvučnog miješanja nanofluida te su utvrdili da u prvih 160 min dolazi do znatnijeg povećanja toplinske vodljivosti, dok se daljnjim produljenjem ultrazvučnog miješanja toplinska vodljivost sporije povećava. Analizom aglomerata MWCNT utvrđeno je da najprije dolazi do smanjivanja aglomerata MWCNT, a daljnjim ultrazvučnim miješanjem i do loma MWCNT u nanofluidu.

Aliev i sur. ${ }^{14}$ istraživali su toplinsku vodljivost ugljikovih nanocijevi te su utvrdili da toplinska vodljivost MWCNT ovisi o prisutnosti strukturnih defekata, ali i broju ugljikovih nanocijevi u snopu kojeg čine linearno povezane MWCNT.
Visoka toplinska vodljivost individualne MWCNT smanjuje se s povećanjem broja MWCNT koje su vezane u snop. Kod dovoljno velikog broja MWCNT toplinska vodljivost se neznatno mijenja daljnjim povećanjem broja MWCNT u snopu.

Prema tome, može se pretpostaviti da se toplinska vodljivost nanofluida s MWCNT povećava prilikom ultrazvučnog miješanja jer dolazi do smanjenja broja MWCNT u nakupini (aglomeratu).

Osim na nanofluidima s MWCNT provedena su istraživanja o utjecaju ultrazvučnog miješanja na toplinsku vodljivost nanofluida s oksidnim nanočesticama. Maheshwary $i$ sur. ${ }^{15}$ istraživali su utjecaj ultrazvučnog miješanja na toplinsku vodljivost vodenih nanofluida s nanočesticama $\mathrm{TiO}_{2}$. Omjer toplinske vodljivosti $\alpha$, koji predstavlja omjer toplinske vodljivosti nanofluida i toplinske vodljivosti baznog fluida, u nanofluidu koji je ultrazvučno miješan 15 min iznosio je 1,543, dok se nakon 60 min miješanja povećao na 1,838. Na temelju SEM i XRD analiza utvrdili su da se tijekom ultrazvučnog miješanja smanjuje veličina čestica $\mathrm{TiO}_{2}$ što za posljedicu ima povećanje toplinske vodljivosti.

Sonawane $i$ sur. $^{16}$ istraživali su utjecaj vremena ultrazvučnog miješanja na toplinsku vodljivost tri vrste nanofluida na

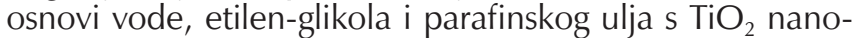
česticama. Na temelju provedenog istraživanja vidljivo je da se toplinska vodljivost povećava do određenog vremena ultrazvučnog miješanja, a potom se smanjuje.

Shahsavar i sur. ${ }^{17}$ ispitivanjem ovisnosti toplinske vodljivosti o vremenu ultrazvučnog miješanja za nanofluide s kombinacijom nanočestica $\mathrm{Fe}_{3} \mathrm{O}_{4}$ i MWCNT-a uz vodu kao bazni fluid također su utvrdili da postoji optimalno vrijeme ultrazvučnog miješanja. Nanofludi su miješani 2,5 - 10 min pri čemu je optimalno vrijeme miješanja bilo $5 \mathrm{~min}$.

\section{Stabilnost nanofluida}

Za primjenu nanofluida vrlo je važna dobra dispergiranost nanočestica jer ona izravno utječe na stabilnost suspenzije kao i na toplinska svojstva nanofluida. Kod nanočestica uvijek postoji velika tendencija stvaranja aglomerata zbog privlačnih van der Waalesovih sila. ${ }^{18}$ Aglomerati čestica znatno brže sedimentiraju nego pojedinačne čestice. Stabilnost koloidnih suspenzija, kakve su i nanofluidi, može se postići elektrostatskom stabilizacijom, polimernim stabilizacijskim sredstvima te površinski aktivnim tvarima. ${ }^{2,8}$

\subsection{Elektrostatska stabilizacija}

Na granici faza između dispergiranih nanočestica i fluida dolazi do razdvajanja naboja i formiranja elektrokemijskog dvosloja. Djelovanjem elektrostatskih odbojnih sila između čestica, odnosno interakcijom elektrokemijskih dvosloja dviju suspendiranih čestica prevladavaju se privlačne sile. ${ }^{23}$ Veličina zeta potencijala često se uzima kao dobra indikacija stabilnosti koloidnih sustava. Kod dovoljno visokih ili niskih vrijednosti zeta potencijala suspendirane čestice 
Tablica 3 - Pregled stabilizacijskih sredstava i sustava bazni fluid/ nanočestice u kojima se upotrebljavaju

Table 3 - Overview of researched surfactants, and base fluid/ nanoparticles systems in which they are used

\begin{tabular}{c|c|c|c}
\hline Bazni fluid & Nanočestice & $\begin{array}{c}\text { Stabilizacijsko } \\
\text { sredstvo }\end{array}$ & Ref. \\
\hline voda & MWCNT & SDS & 12 \\
\hline voda & MWCNT & SDBS & 12 \\
\hline voda & MWCNT & GA & 12,13 \\
\hline voda & MWCNT & kitozan & 19 \\
\hline voda & $\mathrm{Al}_{2} \mathrm{O}_{3}$ & CMC & 20 \\
\hline $\begin{array}{c}\text { transformatorsko } \\
\text { ulje }\end{array}$ & $\mathrm{Cu}$ & $\begin{array}{c}\text { oleinska } \\
\text { kiselina }\end{array}$ & 21 \\
\hline voda & $\mathrm{Cu}$ & SDS & 21 \\
\hline etilen-glikol & $\mathrm{Ag}$ & PVP & 22 \\
\hline $\begin{array}{c}\text { etilen-glikol } \\
\text { voda }\end{array}$ & $\mathrm{Ag}$ & $\mathrm{PVA}$ & 8 \\
\hline
\end{tabular}

SDS - natrijev dodecil-sulfat, SDBS - natrijev dodecil benzensulfonat, GA - arapska guma, PVP - poli(vinil-pirolidon), PVA - poli(vinil-alkohol), CMC - karboksimetil-celuloza

će se odbijati i prevladati privlačne van der Waalsove sile. Kao granična vrijednost zeta potencijala uzima se $\pm 30 \mathrm{mV}$, tako da čestice u suspenzijama sa zeta potencijalom većim od $30 \mathrm{mV}$ i manjim od $-30 \mathrm{mV}$ čine stabilnu suspenziju. ${ }^{23} \mathrm{Na}$ vrijednost zeta potencijala utječe $\mathrm{pH}$ vrijednost te debljina difuznog dijela elektrokemijskog dvosloja koja je određena ionskom jakosti. Nedostatak elektrostatske stabilizacije je što se može primijeniti samo u otapalima koja mogu otopiti ionske spojeve, osjetljiva je na promjenu ionske jakosti otopine te se mogu stabilizirati samo razrijeđene suspenzije. ${ }^{18}$

Osim na stabilnost nanofluida $\mathrm{pH}$ utječe i na toplinsku vodljivost nanofluida. Kod viših odnosno nižih pH vrijednosti u odnosu na neutralan $\mathrm{pH}$ postiže se veća toplinska vodljivost nanofluida. ${ }^{2}$

\subsection{Sterička stabilizacija}

Adsorpcijom polimernih molekula na površinu dispergiranih nanočestica postiže se njihova stabilizacija. Lanci adsorbiranih polimernih molekula stvaraju zaštitni sterički sloj oko dispergiranih čestica. Steričkim odbijanjem dvaju slojeva adsorbiranih polimernih molekula svladavaju se privlačne van der Waalsove sile između dispergiranih čestica. ${ }^{18,23}$

Prednost steričke stabilizacije u odnosu na elektrostatsku je što se može primijeniti i u vodenim i nevodenim medijima, dok je učinkovitost elektrostatske stabilizacije vrlo mala u nevodenom mediju zbog male dielektrične konstante medija. Sterička stabilizacija može se primijeniti kod velikih koncentracija dispergiranih čestica. ${ }^{23}$

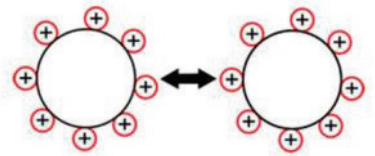

elektrostatička stabilizacija

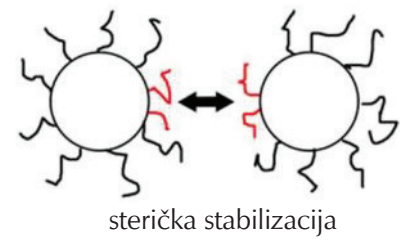

Slika 3 - Shematski prikaz elektrostatičke i steričke stabilizacije ${ }^{24}$ Fig. 3 - Schematic view of electrostatic and steric stabilization ${ }^{24}$

\subsection{Površinski aktivne tvari}

Za stabilizaciju dispergiranih nanočestica također se upotrebljavaju površinski aktivne tvari (PAT). Površinski aktivna tvar sastoji se od hidrofilne (lipofobne) glave, polarnog dijela molekule, i od hidrofobnog (lipofilnog) repa, nepolarnog dijela molekule. Površinski aktivne tvari s kraćim ugljikovodičnim repom imaju bolju topljivost u vodenom mediju, dok dugi ugljikovodični repovi pospješuju topljivost u uljnom mediju. Površinski aktivna tvar smješta se na granicu faza između polarne i nepolarne faze. Polarna glava okreće se prema polarnoj fazi, dok se nepolarni rep okreće prema nepolarnoj fazi te se formira micela. Potrebna je optimalna pokrivenost površine čestica molekulama površinski aktivne tvari kako bi se formirala stabilna micela. ${ }^{25}$

$B o t h a^{8}$ je istraživala nanofluide na osnovi etilen-glikola $s$ nanočesticama srebra. Nanočestice srebra su stabilizirane poli(vinil-pirolidonom) (PVP). Toplinska vodljivost tako pripravljenog nanofluida nije se razlikovala od toplinske vodljivosti etilen-glikola. Kod nanofluida na osnovi etilen-glikola s nanočesticama srebra u kojem nije upotrijebljeno stabilizacijsko sredstvo zabilježeno je povećanje toplinske vodljivosti od 5,2\% kod 0,1 vol. \% nanočestica srebra. Botha navodi da povećanje toplinske vodljivosti nanofluida u kojem su nanočestice srebra stabilizirane s PVP-om nije ostvareno zbog sloja polimernog stabilizacijskog sredstva koji se nalazi oko nanočestica srebra. Sloj PVP-a ponaša se kao toplinski izolator te tako sprječava propagaciju fonona s nanočestice na okolni fluid. ${ }^{8}$

Hojjat i sur. ${ }^{20}$ također su istraživali nanofluide u kojima su nanočestice stabilizirali polimerom. Autori su pripremili tri vrste vodenih nanofluida pri čemu su rabili nanočestice $\mathrm{Al}_{2} \mathrm{O}_{3}, \mathrm{TiO}_{2}$ i $\mathrm{CuO}$ u rasponu udjela $0,1-4$ vol. \%. Nanočestice su stabilizirane s 0,5 mas. \% karboksimetil-celuloze $(\mathrm{CMC})$, a stabilnost nanofluida praćena je vizualno. Nakon nekoliko dana od pripreme nanofluida nije uočena sedimentacija nanočestica. Kod nanofluida s nanočesticama $\mathrm{Al}_{2} \mathrm{O}_{3}$ samo su nanofluidi s 1,5 vol. \% bili stabilni. Kod nižih koncentracija nanočestica $(<1,5$ vol. \%) nije uočeno znatno povećanje toplinske vodljivosti nanofluida. Znatno povećanje toplinske vodljivosti zabilježeno je kod većih koncentracija nanočestica, pa je kod $5{ }^{\circ} \mathrm{C}$ i udjela 4 vol. \% nanočestica zabilježeno povećanje od $12 \%$ kod nanofluida s $\mathrm{TiO}_{2}$, a $22 \%$ povećanje zabilježeno je kod nanofluida s CuO nanočesticama. Za razliku od nanofluida u kojima 
su nanočestice stabilizirane s PVP-om, u sustavu s CMCom zabilježeno je značajno povećanje toplinske vodljivosti, ali tek kod većih volumnih udjela nanočestica.

Sadri i sur. ${ }^{12}$ ispitivali su toplinsku vodljivost baznog fluida u kojem su otopljene tvari koje se upotrebljavaju kao stabilizacijska sredstva. Također, oni su ispitali utjecaj dodatka stabilizacijskog sredstava na toplinsku vodljivost vodenih nanofluida s MWCNT. Ispitivana stabilizacijska sredstva su natrijev dodecil-sulfat, natrijev dodecil benzensulfonat te arapska guma. Toplinska vodljivost baznog fluida smanjila se kada su u bazni fluid (vodu) dodana stabilizacijska sredstva. Najznačajnije smanjenje toplinske vodljivosti destilirane vode (DW) zabilježeno je kod dodatka natrijeva dodecil-sulfata. Smanjenje toplinske vodljivosti otopina izraženije je s povećanjem temperature te s povećanjem koncentracije stabilizacijskog sredstva (slika 4). Kod nanofluida u kojem su MWCNT stabilizirane s GA zabilježeno je naglo povećanje toplinske vodljivosti kod temperatura većih od $30{ }^{\circ} \mathrm{C}$. Kod nanofluida u kojem su MWCNT stabilizirane s SDBS toplinska vodljivost neznatno se promijenila u odnosu na bazni fluid (vodu), dok je kod nanofluida s SDS zabilježeno znatno smanjenje toplinske vodljivosti (slika 5). ${ }^{12}$

Važno je kod odabira stabilizacijskog sredstva uzeti u obzir, osim stabilizacijskih svojstava, njegov utjecaj na toplinsku vodljivost baznog fluida, a time i nanofluida. Utjecaj stabilizacijskog sredstava na toplinsku vodljivost može biti uzrok neslaganja između rezultata različitih istraživača te upućivati na mehanizme prijenosa topline koji ne doprinosi značajno povećanju toplinske vodljivosti.

\section{Toplinska vodljivost nanofluida}

Toplinska vodljivost nanofluida glavno je svojstvo na kojem se temelji primjena nanofluida kao rashladnih fluida. Ra-

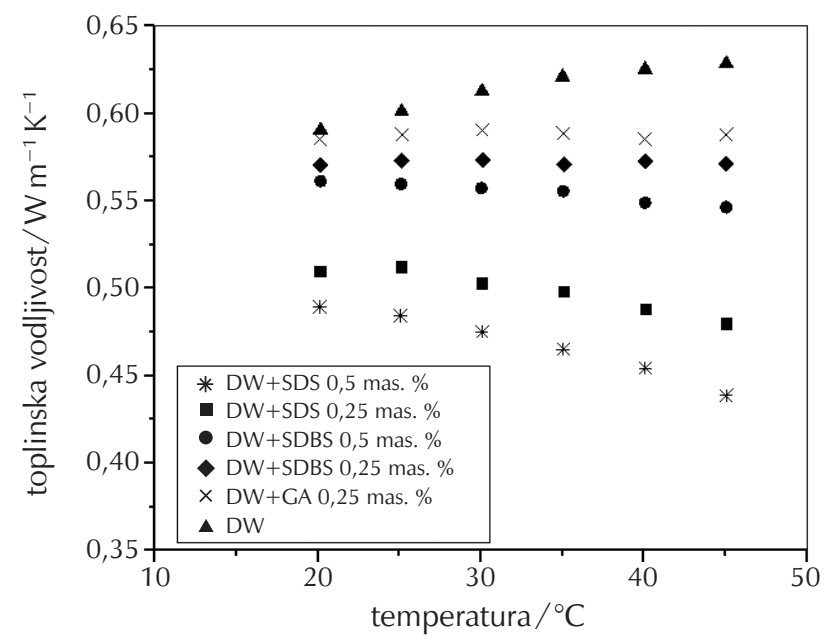

Slika 4 - Utjecaj natrijeva dodecil-sulfata (SDS), natrijeva dodecil benzensulfonata (SDBS) te arapske gume (GA) na toplinsku vodljivost baznog fluida (vode) ${ }^{12}$

Fig. 4 - Effects of sodium dodecyl sulphate (SDS), sodium dodecylbenzenesulphonate (SDBS) and gum arabic (GA) on thermal conductivity of base fluid (distilled water DW) ${ }^{12}$ zvijen je znatan broj teoretskih modela koji služe za procjenu toplinske vodljivosti nanofluida. Međutim, predviđene vrijednosti toplinske vodljivosti nanofluida često odstupaju od eksperimentalnih rezultata. ${ }^{1,4,7}$ Dodatno, postoji neslaganje između rezultata različitih istraživača uglavnom zbog utjecaja veličine čestica na promjenu toplinske vodljivosti nanofluida. ${ }^{2}$

Metoda vruće žice (engl. hot wire method) najčešće se primjenjuje za mjerenje toplinske vodljivosti nanofluida zbog jednostavnosti metode i točnosti mjerenja. Za mjerenje toplinske vodljivosti fluida tom metodom upotrebljava se žica koja je vertikalno uronjena u ispitivani fluid. Uronjena žica služi kao linijski izvor topline te kao mjerno osjetilo temperature. Žica se grije u kratkim vremenskim intervalima a porast temperature žice ovisi o toplinskoj vodljivosti uzorka. ${ }^{2}$

Na temelju istraživanja nađeni su neki parametri o kojima ovisi povećanje toplinske vodljivosti nanofluida, no mehanizam kojim se ostvaruje povećanje toplinske vodljivosti i dalje je nepoznat.7 Povećanje toplinske vodljivosti nanofluida ovisi o udjelu i veličini nanočestica i temperaturi.

Velika pažnja pri istraživanju toplinskih svojstava nanofluida posvećena je nanofluidima na osnovi vode, etilen-glikola i mineralnih ulja s obzirom na to da se ti fluidi vrlo često primjenjuju u industriji kao rashladni medij. ${ }^{1,2,12} \mathrm{U}$ brojnim istraživanjima za pripravu nanofluida su upotrebljavane nanočestice aluminijeva oksida $\left(\mathrm{Al}_{2} \mathrm{O}_{3}\right)$ i bakrova oksida (CuO), zbog niske cijene..$^{1,4,7}$ Također ispituju se $\mathrm{i}$ nanofluidi s ugljikovim nanocijevima za koje je karakteristična vrlo visoka toplinska vodljivost. ${ }^{7,12,26}$ Tako da se već kod malih udjela nanočestica postiže znatno povećanje toplinske vodljivosti baznih fluida (tablica 4).

Xie $i$ sur. ${ }^{27}$ ispitivali su utjecaj toplinske vodljivosti baznog fluida na toplinski vodljivost nanofluida. Ispitivani su nanofluidi na osnovi vode, etilen-glikola i mineralnog ulja s

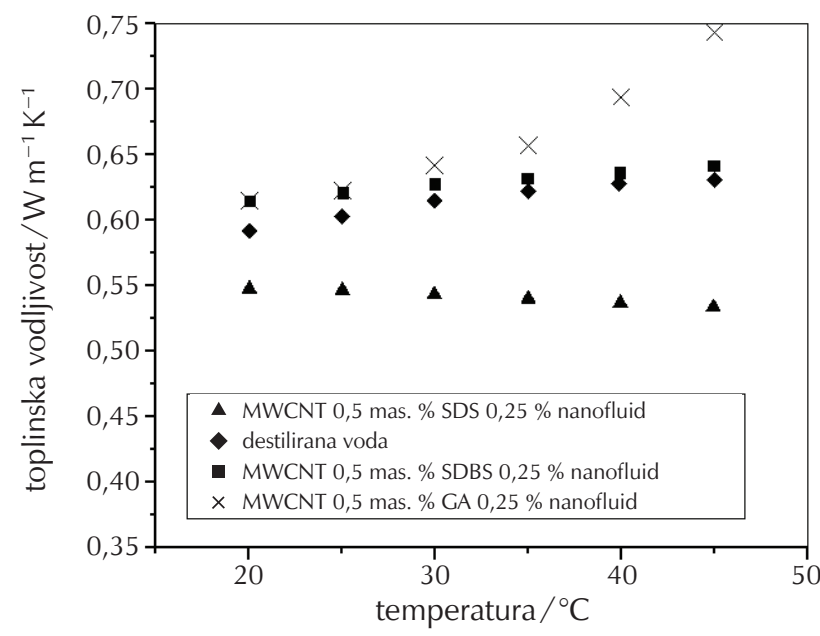

Slika 5 - Utjecaj natrijeva dodecil-sulfata (SDS), natrijeva dodecil benzensulfonata (SDBS) te arapske gume (GA) na toplinsku vodljivost vodeinh nanofluida s višestjenčanim ugljikovim nanocijevima (MWCNT) ${ }^{12}$

Fig. 5 - Effects of sodium dodecyl sulphate (SDS), sodium dodecylbenzenesulphonate (SDBS) and gum arabic (GA) on thermal conductivity of water based nanofluid with multiwall carbon nanotubes (MWCNT) ${ }^{12}$ 
Tablica 4 - Pregled istraživanih nanofluida te ostvarenih povećanja toplinske vodljivosti $(d$ - promjer, $I$ - duljina nanocijevi) Table 4 - Overview of researched nanofluids and their thermal conductivity enhancement $(d$ - diameter, $I$ - length)

\begin{tabular}{c|c|c|c|c|c}
\hline Vrste nanočestica & Prosječna veličina čestica & Volumni udjel/\% & Bazni fluid & $\begin{array}{c}\text { Povećanje toplinske } \\
\text { vodljivosti } \%\end{array}$ & \begin{tabular}{c} 
Ref. \\
\hline $\mathrm{Al}_{2} \mathrm{O}_{3}$
\end{tabular} \\
\hline $\mathrm{Al}_{2} \mathrm{O}_{3}$ & $12 \mathrm{~nm}$ & 4 & voda & 5,5 & 2 \\
\hline $\mathrm{Al}_{2} \mathrm{O}_{3}$ & $12 \mathrm{~nm}$ & 3 & etilen-glikol & 8,6 & 15 \\
\hline $\mathrm{Fe}$ & $33 \mathrm{~nm}$ & 4,3 & voda & 18 & 11 \\
\hline $\mathrm{MWCNT}$ & $10 \mathrm{~nm}$ & 0,55 & poli $(\alpha$-olefinsko $)$ ulje & 150 & 1 \\
\hline $\mathrm{MWCNT}$ & $d(25 \mathrm{~nm}) \times I(50 \mu \mathrm{m})$ & 1 & voda & 38 & 26 \\
\hline $\mathrm{TiO} 2$ & $d(10 \mathrm{~nm}) \times I(40 \mu \mathrm{m})$ & 5,6 & voda & 32,8 & 8 \\
\hline $\mathrm{CuO}$ & $36 \mathrm{~nm}$ & 5 & voda & 60 & 7 \\
\hline $\mathrm{CuO}$ & $50 \mathrm{~nm}$ & 0,4 & voda & 17 & 1 \\
\hline $\mathrm{CuO}$ & $28 \mathrm{~nm}$ & 2 & voda & 10 & 28 \\
\hline
\end{tabular}

5 vol. \% nanočestica $\mathrm{Al}_{2} \mathrm{O}_{3}$. Vrijednosti omjera toplinske vodljivosti nanočestica i baznog fluida $\alpha$ iznose 75 za vodu, 178 za etilen-glikol te 326 za mineralno ulje. Oni su uoči$\mathrm{li}^{27}$ veće povećanje toplinske vodljivosti kod baznih fluida s većom vrijednosti $\alpha$, odnosno kod manje toplinske vodljivosti baznog fluida. Povećanje toplinske vodljivosti kod baznog fluida najmanje toplinske vodljivosti (mineralno ulje) je oko $40 \%$, dok je kod baznog fluida najveće toplinske vodljivosti (voda) oko $23 \% .^{27}$ Ista opažanja potvrđena su i u drugim istraživanjima. ${ }^{2}$

$B_{\text {eck }}{ }^{2}$ je utvrdio da toplinska vodljivost vodenih nanofluida i nanofluida na osnovi etilen-glikola $\mathrm{s}_{2} \mathrm{O}_{3}$ nanočesticama linearno raste $\mathrm{s}$ povećanjem udjela $\mathrm{Al}_{2} \mathrm{O}_{3} \mathrm{u}$ baznom fluidu. Ovisnost toplinske vodljivosti nanofluida ispitana je do 5 vol. $\% \mathrm{Al}_{2} \mathrm{O}_{3}$ u baznom fluidu. Beckovi rezultati slažu se $s$ rezultatima drugih istraživača. ${ }^{4,28}$ Linearna ovisnost povećanja toplinske vodljivosti s porastom udjela nanoče-

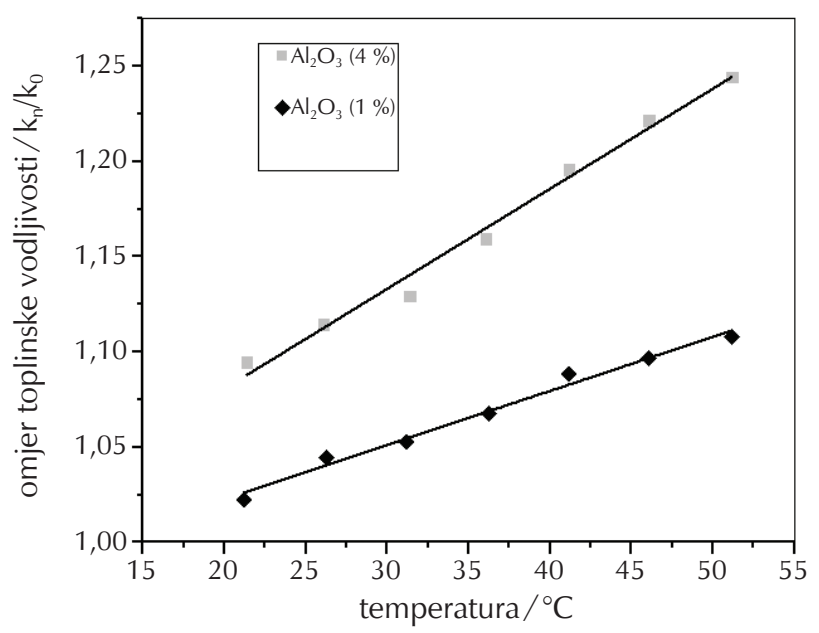

Slika 6 - Utjecaj temperature na povećanje toplinske vodljivosti vodenih nanofluida s 1 vol. $\%$ i 4 vol. $\% \mathrm{Al}_{2} \mathrm{O}_{3}{ }^{28}$

Fig. 6 - Effect of temperature on thermal conductivity enhancement of water based nanofluid with 1 vol\% and 4 vol\% of $\mathrm{Al}_{2} \mathrm{O}_{3}{ }^{28}$ stica u baznom fluidu također je zabilježena za nanofluide s $\mathrm{CuO} .^{2,28}$ Međutim, toplinska vodljivost nanofluida ne povećava se uvijek linearno s povećanjem udjela nanočestica. Kod nanofluida s ugljikovim nanocijevima, nanočesticama cinkova oksida, zlata i željeza nije zabilježeno linearno povećanje toplinske vodljivosti s porastom udjela nanočestica. ${ }^{1,11}$

Ispitivanja utjecaja temperature na toplinsku vodljivost nanofluida pokazala su porast toplinske vodljivosti s porastom temperature. Istraživanja se uglavnom provode u temperaturnom području $20-90{ }^{\circ} \mathrm{C} ., 12,28$ Das $i$ sur. ${ }^{28}$ ispitali su utjecaj temperature na toplinsku vodljivost vodenih nanofluida s nanočesticama $\mathrm{Al}_{2} \mathrm{O}_{3}$ i $\mathrm{CuO}$ u temperaturnom području $21-52{ }^{\circ} \mathrm{C}$. Ustanovili su linearan porast toplinske vodljivosti s porastom temperature $u$ ispitivanom području kao što to slike 6 i 7 pokazuju.

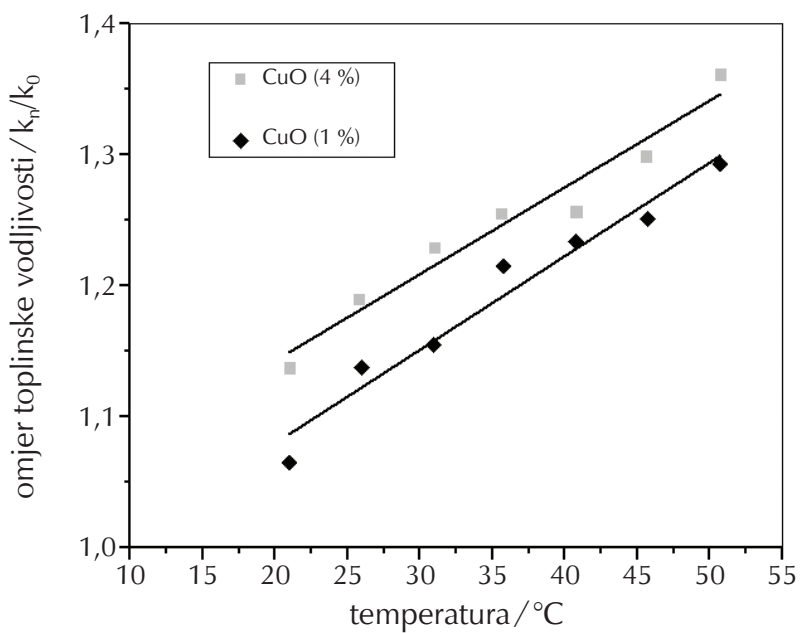

Slika 7 - Utjecaj temperature na povećanje toplinske vodljivosti vodenih nanofluida s 1 vol. \% i 4 vol. \% $\mathrm{CuO}^{28}$

Fig. 7 - Effect of temperature on thermal conductivity enhancement of water based nanofluid with 1 vol\% and 4 vol\% of $\mathrm{CuO}^{28}$ 


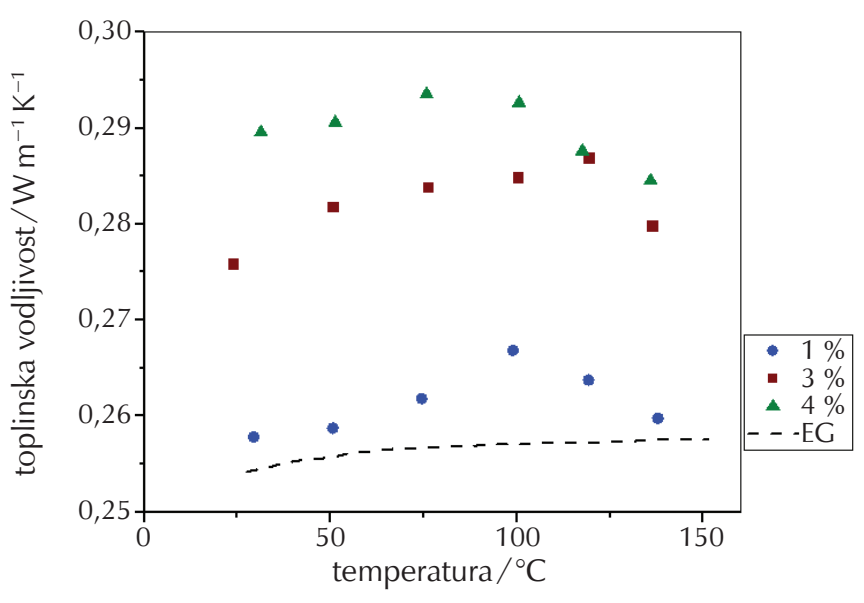

Slika 8 - Utjecaj temperature na toplinsku vodljivost nanofluida na osnovi etilen-glikola (EG) s 1 vol. \%, 3 vol. \% i 4 vol. $\% \mathrm{Al}_{2} \mathrm{O}_{3}{ }^{2}$

Fig. 8 - Effect of temperature on thermal conductivity of ethylene glycol based nanofluid with 1 vol\%, 3 vol\%, and 4 vol\% $\mathrm{Al}_{2} \mathrm{O}_{3}{ }^{2}$

Predodžba o utjecaju temperature na toplinsku vodljivost nanofluida je nepotpuna s obzirom da su ispitivanja provedena u uskom temperaturnom području. Beck ${ }^{2}$ je ispitivao nanofluide na osnovi vode, etilen-glikola $(\mathrm{EG})$ te njihove mješavine (50/50 vol. \%) s nanočesticama $\mathrm{Al}_{2} \mathrm{O}_{3}$ u širem temperaturnom području $\left(21-147^{\circ} \mathrm{C}\right)$. Rezultati istraživanja pokazuju da toplinska vodljivost nanofluida prati porast toplinske vodljivost baznog fluida te postiže maksimalnu vrijednost kod približno iste temperature kao u baznom fluidu (slike 8 i 9). ${ }^{2}$ Sličan trend porasta toplinske vodljivosti baznog fluida i nanofluida upućuje na to da je isti mehanizam zaslužan za povećanje toplinske vodljivosti u oba fluida. Prema tome, može se očekivati smanjenje toplinske vodljivosti nanofluida ako bazni fluid pokazuje smanjenje toplinske vodljivosti s povećanjem temperature. ${ }^{29}$

Toplinska vodljivost vodenih nanofluida s MWCNT također raste $\mathrm{s}$ porastom temperature. Sadri $i$ sur. ${ }^{12}$ ispitivali su utjecaj temperature na vodene nanofluide s 0,5 vol. $\%$ MWCNT-a u temperaturnom području $20-45{ }^{\circ} \mathrm{C}$. Za stabilizaciju višestjenčanih ugljikovih nanocijevi upotrijebljena je arapska guma. Također su ispitali utjecaj vremena ultrazvučnog miješanja na toplinsku vodljivost pripremljenog nanofluida. Utvrdili su da toplinska vodljivost nanofluida blago raste s porastom temperature, pri čemu iznad $30{ }^{\circ} \mathrm{C}$ dolazi do naglog porasta toplinske vodljivosti. Taj porast izraženiji je kod uzoraka koji su dulje vrijeme ultrazvučno miješani (slika 10). ${ }^{12}$ Autori navode da je mogući uzrok takvog povećanja toplinske vodljivosti Brownovo gibanje nanočestica koje raste $\mathrm{s}$ porastom temperature i smanjenjem veličine čestica. Brownovo gibanje nanočestica uzrokuje pojavu mikro ili nanokonvekcije u nanofluidu. ${ }^{12,29}$ Ultrazvučnim miješanjem najprije dolazi do razbijanja aglomerata ugljikovih nanocijevi, a daljnjim ultrazvučnim miješanjem dolazi do njihova loma. ${ }^{12}$ Brownovo gibanje izraženije je kod manjih čestica, te se prema tome veća toplinska vodljivost očekuje kod nanofluida s kraćim ugljikovim nanocijevima. Keblinski i sur. ${ }^{29}$ navode da je glavni

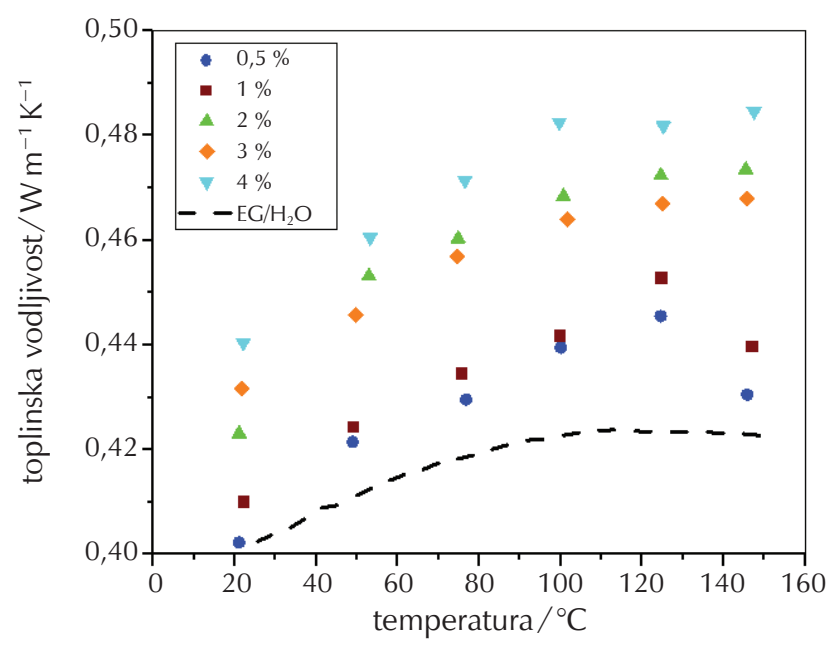

Slika 9 - Utjecaj temperature na toplinsku vodljivost nanofluida na osnovi mješavine etilen-glikola i vode (50/50 vol. \%) s $0,5,1,2,3$ i 4 vol. $\% \mathrm{Al}_{2} \mathrm{O}_{3}{ }^{2}$

Fig. 9 - Effect of temperature on thermal conductivity of ethylene glycol/water (50/50 vol. \%) based nanofluid with $0.5,1,2,3$, and 4 vol $\% \mathrm{Al}_{2} \mathrm{O}_{3}{ }^{2}$

nedostatak koncepta mikro i nanokonvekcije uzrokovanih Brownovim gibanjem nanočestica to što je toplinska difuzivnost a, koja je mjera brzine promjene temperature kapljevine, ${ }^{30}$ za nekoliko redova veličine veća od difuzivnosti nanočestica $D_{n}$, koja je mjera brzine prijenosa mase zbog difuzije nanočestica. S obzirom na navedeno, utjecaj nanokonvekcije je zanemariv, odnosno Brownovo gibanje nanočestica je presporo da bi se tim mehanizmom prenijela značajna količina topline kroz nanofluid. ${ }^{27}$ Osim toga, duljina ugljikovih nanocijevi mikrometarskih je dimenzija te je njihovo Brownovo gibanje zanemarivo. ${ }^{31}$

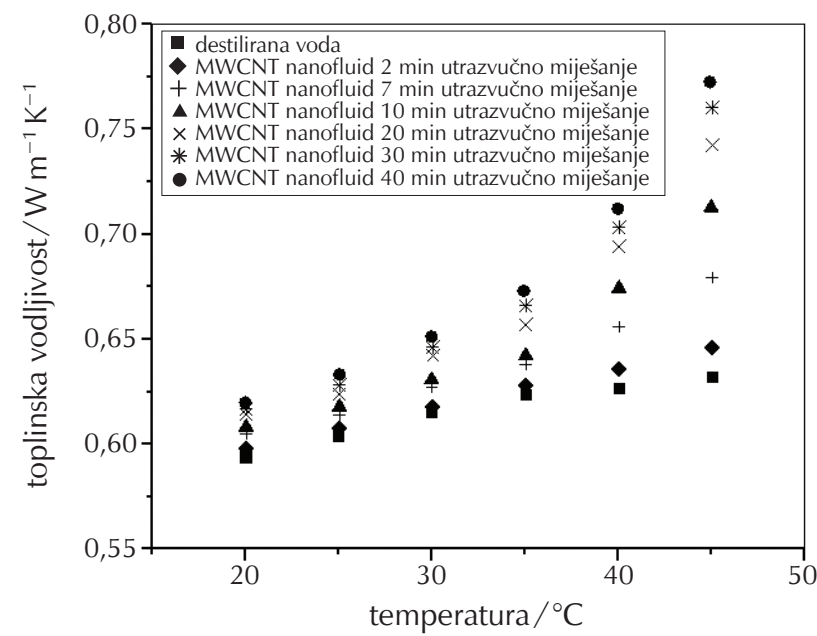

Slika 10 - Utjecaj ultrazvučnog miješanja i temperature na toplinsku vodljivost vodenih nanofluida s višestjenčanim ugljikovim nanocijevima ${ }^{12}$

Fig. 10 - Effect of sonication time and temperature on thermal conductivity of water based nanofluid with multiwall carbon nanotubes ${ }^{12}$ 
Assael $i$ sur. ${ }^{26}$ su utvrdili da je toplinska vodljivost vodenih nanofluida s MWCNT veća kod duljih MWCNT jer se dulje ugljikove nanocijevi isprepliću i tvore homogenu mrežu kroz uzorak. U tom radu za stabilizaciju MWCNT-a upotrijebljen je natrijev dodecil-sulfat. Oni su utvrdili da se toplinska vodljivost nanofluida smanjuje s povećanjem vremena ultrazvučnog miješanja, a istovremeno smanjuje se duljina MWCNT. Mogući razlog neslaganja eksperimentalnih rezultata Assaela i sur. ${ }^{26}$ i eksperimentalnih rezultata Sadria i sur. ${ }^{12}$ je upotreba različitog stabilizacijskog sredstva kao i razlike u toplinskim svojstvima upotrjebljenih višestjenčanih ugljikovih nanocijevi.

Kod vodenih nanofluida s nanočesticama $\mathrm{Al}_{2} \mathrm{O}_{3}$ ustanovljeno je da se toplinska vodljivost nanofluida smanjuje sa smanjenjem veličine čestica ispod određene veličine (slika 11). ${ }^{2}$

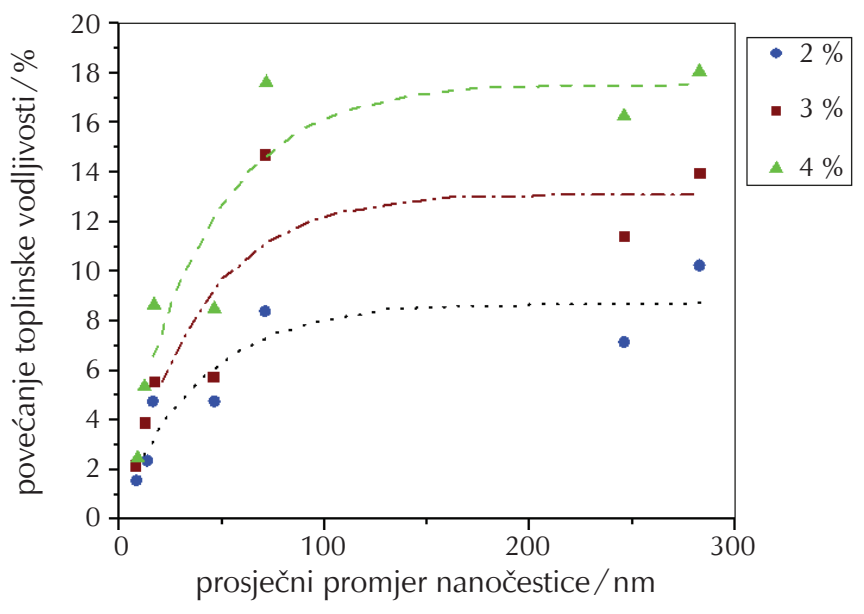

Slika 11 - Povećanje toplinske vodljivosti vodenih nanofluida s 2, 3 i 4 vol. \% $\mathrm{Al}_{2} \mathrm{O}_{3}$. Iscrtane linije dodane su da bi prikazale trend promjene povećanja toplinske vodljivosti s promjenom veličine čestica. ${ }^{2}$

Fig. 11 - Thermal conductivity enhancement of water based nanofluid with 2, 3 i 4 vol\% $\mathrm{Al}_{2} \mathrm{O}_{3}$. Empirical curve fits are provided to aid in visual detection of trends in the data. $^{2}$

$B e c k^{2}$ navodi da je smanjenje toplinske vodljivosti nanofluida s manjim nanočesticama posljedica smanjenja toplinske vodljivosti nanočestica u odnosu na materijal makroskopskih dimenzija. Na temelju istraživanja toplinske vodljivosti poluvodiča i izolatora utvrđeno je da je toplinska vodljivost tankih filmova $(<100 \mathrm{~nm})$ i nanožica manja od toplinske vodljivosti materijala makroskopskih dimenzija. Pojedina tumačenja navode da je smanjenje toplinske vodljivosti materijala posljedica ograničavanja kretanja vala fonona s obzirom na to da je debljina nanomaterijala istog reda veličine kao i srednji slobodni put fonona. Toplinska vodljivost nanožica manja je od toplinske vodljivosti tankih filmova te se očekuje da je toplinska vodljivost nanočestica manja od toplinske vodljivosti nanožica jer se u istom redoslijedu ograničava prostiranje vala fonona. ${ }^{2,32}$

U literaturi su zabilježeni i oprečni rezultati, to jest povećanje toplinske vodljivosti nanofluida kod smanjenja veličine čestica ispod određene veličine. Kao objašnjenje takvog porasta toplinske vodljivosti u literaturi se navodi formiranje sloja kapljevine u kojem su molekule pravilno poredane na međupovršini između nanočestica i kapljevine (engl. liquid nano-layer). ${ }^{33}$

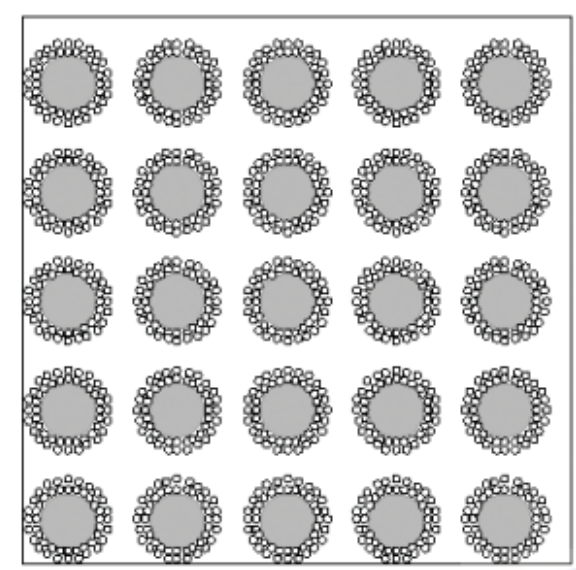

Slika 12 - Shematski prikaz uređenog nanosloja kapljevine na međupovršini nanočestica/kapljevina) ${ }^{34}$

Fig. 12 - Schematic of ordered liquid nanolayer at solid/liquid interface $^{34}$

Prema analogiji s krutinama, koje imaju bolja svojstva provođenja topline nego kapljevine, može se očekivati da takav sloj kapljevine ima veću toplinsku vodljivost od kapljevine u masi i tako doprinosi toplinskoj vodljivosti nanofluida. $^{3}$

No Keblinski i sur. ${ }^{3}$ navode da formirani sloj kapljevine na međupovršini nanočestica/kapljevina ne pridonosi značajno povećanju toplinske vodljivosti s obzirom na to da je eksperimentalno i na temelju računalne simulacije utvrđeno da je debljina takvog sloja do $1 \mathrm{~nm}$, što je mnogo manje od debljine sloja koja bi značajno doprinijela toplinskoj vodljivosti nanofluida. ${ }^{3}$

\section{Modeli toplinske vodljivosti}

Odstupanje eksperimentalnih vrijednosti toplinske vodljivosti od vrijednosti procijenjenih na temelju klasičnih modela (Maxwellov mode, $\mathrm{H}-\mathrm{C}$ model) potaknulo je razvoj znatnog broja modela koji pokušavaju objasniti anomalije kod promjene toplinske vodljivosti nanofluida.

Maxwellov model ${ }^{35}$ (jedn. 1) izveden je za razrijeđene suspenzije sferičnih čestica između kojih nema međudjelovanja te podrazumijeva da su čestice statične u odnosu na bazni fluid.

$$
\frac{k_{\mathrm{nf}}}{k_{\mathrm{bf}}}=1+\frac{3 \cdot\left(\frac{k_{\mathrm{p}}}{k_{\mathrm{bf}}}-1\right) \cdot \varphi}{\left(\frac{k_{\mathrm{p}}}{k_{\mathrm{bf}}}+2\right)-\left(\frac{k_{\mathrm{p}}}{k_{\mathrm{bf}}}-1\right) \cdot \varphi},
$$


gdje je $k_{\text {nf }}$ - toplinska vodljivost nanofluida $\left(\mathrm{W} \mathrm{m}^{-1} \mathrm{~K}^{-1}\right)$, $k_{\mathrm{bf}}-$ toplinska vodljivost baznog fluida $\left(\mathrm{W} \mathrm{m}^{-1} \mathrm{~K}^{-1}\right), k_{\mathrm{p}}-$ toplinska vodljivost čestice $\left(\mathrm{W} \mathrm{m}^{-1} \mathrm{~K}^{-1}\right), \varphi$ - volumni udio čestica.

Iz jedn. (1) vidljivo je da toplinska vodljivost suspenzije ovisi samo o toplinskoj vodljivosti baznog fluida, toplinskoj vodljivosti čestica te volumnom udjelu čestica. Hamilton $i$ Crosser $^{36}$ proširili su Maxwellov model kako bi uzeli u obzir utjecaj oblika čestica na toplinsku vodljivost suspenzije.

$$
k_{\mathrm{nf}}=k_{\mathrm{bf}}\left[\frac{k_{\mathrm{p}}+(n-1) \cdot k_{\mathrm{bf}}-(n-1) \cdot \varphi \cdot\left(k_{\mathrm{bf}}-k_{\mathrm{p}}\right)}{k_{\mathrm{bf}}+(n-1) \cdot k_{\mathrm{bf}}+\varphi \cdot\left(k_{\mathrm{bf}}-k_{\mathrm{p}}\right)},\right.
$$

gdje je $k_{\mathrm{nf}}$ - toplinska vodljivost nanofluida $\left(\mathrm{W} \mathrm{m}^{-1} \mathrm{~K}^{-1}\right), k_{\mathrm{bf}}$ - toplinska vodljivost baznog fluida $\left(\mathrm{W} \mathrm{m}^{-1} \mathrm{~K}^{-1}\right), k_{\mathrm{p}}-$ toplinska vodljivost čestice $\left(\mathrm{W} \mathrm{m}^{-1} \mathrm{~K}^{-1}\right), \varphi$ - volumni udio čestica, $n-$ faktor oblika čestice.

Faktor oblika čestica definiran je sljedećom jednadžbom:

$$
n=\frac{3}{\psi}
$$

gdje je $n$ - faktor oblika čestice, $\psi$ - sfericitet (omjer površine sfere, čiji je volumen jednak volumenu čestice, te površine čestice).

Kod sferičnih čestica, sfericitet je jednak jedinici te se model Hamiltona i Crossera svodi na Maxwellov model. Navedeni modeli često predviđaju niže vrijednosti toplinske vodljivosti nanofluida u odnosu na eksperimentalne vrijednosti. ${ }^{6,37}$

Nanočestice dodane $u$ bazni fluid pod djelovanjem van der Waalesovih sila formiraju aglomerate. Na temelju toga, Keblinski i sur. ${ }^{29}$ navode da je glavni razlog odstupanja eksperimentalnih vrijednosti taj što se uspoređuju podatci s teorijskim modelima koji podrazumijevaju dobru disperziju sferičnih čestica.

Kako bi se objasnila toplinska vodljivost nanofluida koja odstupa od klasičnih modela Maxwella i Hamiltona i Crossera, izvedeni su modeli koji se temelje na Brownovom gibanju čestica, uređenom sloju molekula na međupovršini čestice i kapljevine, pojavi mikro konvekcije i smanjenoj toplinskoj vodljivosti nanočestica. ${ }^{34,38,39}$

Koo i Kleinstruer ${ }^{38}$ proširili su Maxwellov model tako što su u obzir uzeli doprinos Bownova gibanja toplinskoj vodljivosti nanofluida. Prema tome, toplinska vodljivost nanofluida predstavlja zbroj doprinosa toplinske vodljivosti statične suspenzije $\left(k_{\text {statično }}\right)$ i doprinosa toplinske vodljivosti Brownova miješanja $\left(k_{\text {Brownovo }}\right)$. Toplinska vodljivost statične suspenzije definirana je Maxwellovim modelom (jedn. 1), dok je toplinska vodljivost Brownova miješanja definirana jedn. 5 .

$$
\begin{gathered}
k_{\mathrm{nf}}=k_{\text {statično }}+k_{\text {Brownovo }} \\
k_{\text {Brownovo }}=5 \cdot 10^{4} \beta \varphi \rho_{\mathrm{l}} C_{\mathrm{l}} \sqrt{\frac{\kappa T}{\rho_{\mathrm{d}} D}} f(T, \varphi, \ldots),
\end{gathered}
$$

gdje je $\beta$ - funkcija, $\varphi$ - volumni udio čestica, $\rho_{l}-$ gustoća baznog fluida $\left(\mathrm{kg} \mathrm{m}^{-3}\right), \rho_{\mathrm{d}}$ - gustoća nanočestica $\left(\mathrm{kg} \mathrm{m}^{-3}\right)$, $c_{\text {I }}$ - specifični toplinski kapacitet baznog fluida $\left(\mathrm{J} \mathrm{kg}^{-1} \mathrm{~K}^{-1}\right)$, $\kappa$ - Boltzmanova konstanta $\left(\mathrm{J} \mathrm{K}^{-1}\right), D$ - promjer nanočestice (m), f-funkcija.

Brownovo gibanje čestica doprinosi toplinskoj vodljivosti nanofluida povlačenjem dijela fluida oko čestice prilikom pomicanja pri čemu nastaje nanomiješanje (nanokonvekcija). Funkcija $\beta$ uzima u obzir da se dio volumena fluida koji čestica povlači za sobom sudara s dijelom fluida koji povlači druga čestica te taj dio volumena fluida ne doprinosi toplinskoj vodljivosti nanofluida. Interakcije između čestica uzimaju se u obzir kroz funkciju $f$ koja je funkcija temperature i volumnog udjela čestica u nanofluidu.

Yu i Choi ${ }^{34}$ uvode koncept u kojem se na međufaznoj granici između nanočestice i baznog fluida nalazi nanosloj molekula baznog fluida uređenije strukture u odnosu na okolni fluid. Na temelju toga autori definiraju ekvivalentnu česticu koja se sastoji od nanočestice te nastalog nanosloja oko čestice. Potom je definirana toplinska vodljivost ekvivalentne čestice $\left(k_{\mathrm{e}}\right)$ koja je funkcija toplinske vodljivosti nanočestice i toplinske vodljivosti nanosloja. Toplinska vodljivost ekvivalentne čestice $\left(k_{\mathrm{e}}\right)$ dana je jedn. 6:

$$
k_{\mathrm{e}}=\frac{\left[2(1-\gamma)+\left(1+\beta^{\prime}\right)^{3}(1+2 \gamma)\right] \gamma}{\left(1+\beta^{\prime}\right)^{3}(1+2 \gamma)-(1-\gamma)} k_{\mathrm{p}},
$$

gdje je $k_{\mathrm{e}}$ - toplinska vodljivost ekvivalentne čestice $\left(\mathrm{W} \mathrm{m}^{-1} \mathrm{~K}^{-1}\right), k_{\mathrm{p}}$ - toplinska vodljivost nanočestice $\left(\mathrm{W} \mathrm{m} \mathrm{m}^{-1} \mathrm{~K}^{-1}\right), \gamma-$ omjer toplinske vodljivosti nanosloja i toplinske vodljivosti nanočestice, $\beta^{\prime}$ - omjer debljine nanosloja i radijusa nanočestice.

Uvrštavanjem jedn. 6 u Maxwellov model (jedn. 1) dobiva se Yu Choi model koji je dan jedn. 7:

$$
k_{\mathrm{nf}}=\frac{k_{\mathrm{e}}+2 k_{\mathrm{bf}}+2\left(k_{\mathrm{e}}-k_{\mathrm{bf}}\right)\left(1+\beta^{\prime}\right)^{3} \varphi}{k_{\mathrm{e}}+2 k_{\mathrm{bf}}-\left(k_{\mathrm{e}}-k_{\mathrm{bf}}\right)\left(1+\beta^{\prime}\right)^{3} \varphi} k_{\mathrm{bf}},
$$

gdje je $k_{n f}$ - toplinska vodljivost nanofluida $\left(\mathrm{W} \mathrm{m}^{-1} \mathrm{~K}^{-1}\right)$, $k_{\text {bf }}$ - toplinska vodljivost baznog fluida $\left(\mathrm{W} \mathrm{m}^{-1} \mathrm{~K}^{-1}\right), k_{\mathrm{e}}-$ toplinska vodljivost ekvivalentne čestice $\left(\mathrm{W} \mathrm{m}^{-1} \mathrm{~K}^{-1}\right), \varphi-v o-$ lumni udio čestica, $\beta^{\prime}$ - omjer debljine nanosloja i radijusa nanočestice.

Prema modelu Yanga i Choia ${ }^{39}$ toplinska vodljivost nanofluida linearna je kombinacija četiriju doprinosa:

1. doprinos: prijenos topline međusobnim sudarom molekula baznog fluida (toplinska kondukcija),

2. doprinos: difuzija topline u nanočesticama pri čemu se uzima u obzir veličina čestica i Kapitza otpor (otpor prijelazu topline na međupovršini čestica/kapljevina),

3. doprinos: sudar čestica zbog Brownova gibanja,

4. doprinos: nanokonvekcija stvorena Brownovim gibanjem čestice dana jedn. 8 . 


$$
k_{\mathrm{nf}}=k_{\mathrm{bf}}(1-\varphi) \beta k_{\mathrm{p}} \varphi+C \frac{d_{\mathrm{bf}}}{d_{\mathrm{p}}} k_{\mathrm{bf}} \operatorname{Re}_{d_{\mathrm{p}}} \operatorname{Pr} \varphi,
$$

gdje je $k_{\mathrm{nf}}$ - toplinska vodljivost nanofluida $\left(\mathrm{W} \mathrm{m}^{-1} \mathrm{~K}^{-1}\right)$, $k_{\mathrm{bf}}$ - toplinska vodljivost baznog fluida $\left(\mathrm{W} \mathrm{m}^{-1} \mathrm{~K}^{-1}\right), \beta^{\prime \prime}-$ konstanta koja uzima u obzir Kapitza otpor po jediničnoj površini, $\varphi$-volumni udio čestica, $d_{\mathrm{p}}$ - ekvivalntni promjer nanočestice, $d_{b f}-$ ekvivalentni promjer molekule baznog fluida.

\subsection{Primjena modela umjetne inteligencije za modeliranje toplinskih svojstava nanofluida}

$\mathrm{U}$ posljednjih nekoliko godina provedeno je modeliranje toplinske vodljivosti primjenom algoritama umjetne inteligencije (AI) pri čemu je u obzir uzet volumni udio čestica u nanofluidu, temperatura, toplinska vodljivost nanočestica. ${ }^{40}$ Pod umjetnom inteligencijom podrazumijeva se mogućnost računala za izvršavanja procesa za koje je potrebna umjetna inteligencija. $U$ modeliranju toplinske vodljivosti nanofluida Al metodom često se primjenjuje metoda umjetne neuronske mreže, pri čemu se neuronska mreža sastoji od ulaznog, skrivenog i izlaznog sloja. ${ }^{41}$

Hojjat $i$ sur. ${ }^{20}$ modelirali su toplinsku vodljivost vodenih nanofluida s nanočesticama $\mathrm{Al}_{2} \mathrm{O}_{3}, \mathrm{TiO}_{2}$ i $\mathrm{CuO}$ pomoću umjetnih neuronskih mreža pri čemu su u obzir uzeli volumni udio nanočestica, temperaturu i toplinsku vodljivost nanočestica. Autori su model umjetne neuronske mreže usporedili s predviđanjem toplinske vodljivosti na temelju modela Hamiltona i Crossera. Toplinska vodljivost nanofluida nije se znatno povećala do 1,5 vol. \% nanočestica, dok je zabilježeno znatno povećanje toplinske vodljivost daljnjim povećanjem koncentracije nanočestica do 4 vol. \%. Pri temperaturi od $45{ }^{\circ} \mathrm{C}$ i udjelu nanočestica od 4 vol. \% zabilježeno je povećanje toplinske vodljivosti od $22 \%$ za nanofluid s $\mathrm{TiO}_{2}$, dok je za nanofludi s $\mathrm{CuO}$, kod iste temperature i udjela nanočestica, zabilježeno povećanje od $76 \%$. Previđanja toplinske vodljivosti na temelju umjetnih neuronskih mreža slagala su se s eksperimentalnim podatcima, dok je model Hamiltona i Crossera znatno odstupao od eksperimentalnih podataka predviđajući linearno povećanje toplinske vodljivosti s povećanjem volumnog udjela nanočestica.

Hemmat Esfe i sur. ${ }^{42}$ također su primijenili metodu umjetnih neuronskih mreža za modeliranje toplinske vodljivosti nanofluida. Autori su pripremili nanofluid s nanočesticama $\mathrm{Cu} \mathrm{i} \mathrm{TiO}_{2}$ pri čemu je mješavina vode i etilen-glikola upotrijebljena kao bazni fluid. Za modeliranje toplinske vodljivosti nanofluida primijenili su neuronsku mrežu s dva skrivena sloja, a temperatura i volumni udio nanočestica su parametri upotrijebljeni za ulazni sloj neuronske mreže (slika 13). Kao i u slučaju Hojjat i sur. ${ }^{20}$ dobiveno je dobro slaganje eksperimentalnih vrijednosti s vrijednostima predviđenim na temelju modela.

Hemmat Esfe i sur. ${ }^{43}$ razvili su umjetnu neuronsku mrežu za modeliranje viskoznosti i toplinske vodljivosti nanofluida na osnovi etilen-glikola s nanočesticama Fe, pri čemu su kao ulazni parametri za neuronsku mrežu upotrijebljeni temperatura, promjer nanočestica i volumni udio nanočestica u nanofluidu. Vrijednosti toplinske vodljivosti nanofluida, predviđene na temelju razvijene umjetne neuronske mreže, odstupale su $2 \%$ od eksperimentalnih vrijednosti, dok su vrijednosti dinamičke viskoznosti nanofluida odstupale $2,5 \%$. Afrand i sur. ${ }^{44}$ također su razvili neuronsku mrežu za predviđanje viskoznosti nanofluida, pri čemu su vrijednosti viskoznosti za vodeni nanofluid s MWCNT-om predviđene umjetnom neuronskom mrežom odstupale od eksperimentalnih vrijednosti za 0,28 \%.

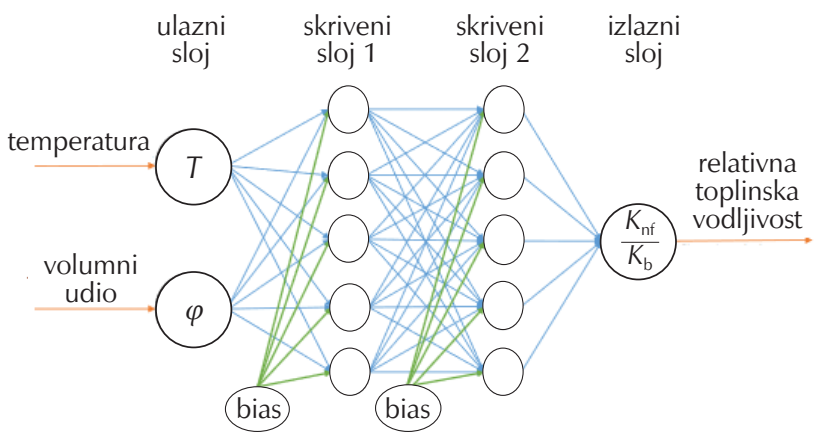

Slika 13 - Prikaz sheme umjetne neuronske mreže primijenjene za modeliranje toplinske vodljivosti nanofluida ${ }^{42}$

Fig. 13 - Schematic overview of artificial neural network used for modelling of thermal conductivity of nanofluids ${ }^{42}$

\section{Zaključak}

Pregledom dosadašnjih istraživanja vidljivo je da je područje nanofluida složena tematika s obzirom na to da postoji neslaganje oko utjecaja pojedinih parametara na toplinsku vodljivost nanofluida. Toplinska vodljivost baznih fluida uglavnom se povećava dodatkom i malih udjela nanočestica. U literaturi je utvrđeno da na toplinsku vodljivost nanofluida utječe metoda priprave nanofluida, udio nanočestica, vrsta i velična nanočestica, toplinska vodljivost baznog fluida, temperatura i stabilizacijsko sredstvo. Često primjenjivana metoda za pripravu nanofluida je metoda u dva koraka kod koje je važan parametar vrijeme ultrazvučnog miješanja te odabir stabilizacijskog sredstva. Prilikom izbora stabilizacijskog sredstva za nanočestice, osim stabilizacijskih svojstava, važno je uzeti u obzir njegov utjecaj na toplinsku vodljivost baznog fluida. U literaturi se povećanje toplinske vodljivosti nanofluida pokušava objasniti Brownovim gibanjem čestica, otporom prijelazu topline na međupovršini čestica/kapljevina, formiranjem nepokretnog sloja molekula baznog fluida oko nanočestica i pojavom nanokonvekcije. Modeli razvijeni na spomenutim pretpostavkama dobro se slažu s eksperimentalnim vrijednostima toplinske vodljivosti kod određenog broja nanofluida. Nešto bolje predviđanje toplinske vodljivosti postignuto je primjenom algoritama umjetne inteligencije. 


\section{Popis kratica i simbola \\ List of abbreviations and symbols}

$k_{\mathrm{nf}} \quad-$ toplinska vodljivost nanofluida, $\mathrm{W} \mathrm{m}^{-1} \mathrm{~K}^{-1}$ - thermal conductivity of nanofluid, $\mathrm{W} \mathrm{m}^{-1} \mathrm{~K}^{-1}$

$k_{\mathrm{bf}} \quad-$ toplinska vodljivost baznog fluida, $\mathrm{W} \mathrm{m}^{-1} \mathrm{~K}^{-1}$ - thermal conductivity of base fluid, $\mathrm{W} \mathrm{m}^{-1} \mathrm{~K}^{-1}$

$k_{\mathrm{p}} \quad-$ toplinska vodljivost nanočestice, $\mathrm{W} \mathrm{m}^{-1} \mathrm{~K}^{-1}$ - thermal conductivity of nanoparticle, $\mathrm{W} \mathrm{m}^{-1} \mathrm{~K}^{-1}$

- volumni udio čestica, vol. \%

- particle volume fraction, vol. \%

- faktor oblika čestice

- particle shape factor

- sfericitet

- sphericity

- omjer toplinske vodljivosti

- ratio of thermal conductivity

$\beta \quad-$ funkcija

- function

$\rho_{\mathrm{l}}$

- gustoća baznog fluida, $\mathrm{kg} \mathrm{m}^{-3}$

- density of base fluid, $\mathrm{kg} \mathrm{m}^{-3}$

$\rho_{\mathrm{d}} \quad-$ gustoća nanočestica, $\mathrm{kg} \mathrm{m}^{-3}$

- density of nanoparticles, $\mathrm{kg} \mathrm{m}^{-3}$

$C_{1}$

$k_{\mathrm{e}}$

$d_{\mathrm{p}} \quad-$ ekvivalentni promjer nanočestice

- nanoparticle equivalent diameter

$d_{\mathrm{bf}} \quad-$ ekvivalentni promjer molekule baznog fluida

- equivalent diameter of the base fluid molecule

- toplinska difuzivnost, $\mathrm{m}^{2} \mathrm{~s}^{-1}$

- thermal diffusivity, $\mathrm{m}^{2} \mathrm{~s}^{-1}$

MWCNT - višestjenčane ugljikove nanocijevi

- multicellular carbon nanotubes

SDS - natrijev dodecil-sulfat

- sodium dodecyl sulphate
SDBS

- natrijev dodecil benzensulfonat

- sodium dodecylbenzenesulphonate

GA - arapska guma

- gum arabic

PVP $\quad-$ poli(vinil-pirolidon)

- poly(vinyl pyrrolidone)

PVA - poli(vinil-alkohol)

- poly(vinyl alcohol)

CMC - karboksimetil-celuloza

- carboxymethyl cellulose

\section{Literatura}

References

1. R. Saidur, K. Y. Leong, H. A. Mohammad, A review on applications and challenges of nanofluids, Renew. Sustain. Energy Rev. 15 (2011) 1646-1668, doi: https://doi.org/10.1016/j. rser.2010.11.035.

2. M. P. Beck, doktorska disertacija, Thermal conductivity of metal oxide nanofluids, Georgia Institute of Technology, (2008).

3. P. Keblinski, S. R. Phillpot, S. U. S. Choi, J. A. Eastman, Mechanisms of heat flow in suspensions of nano-sized particles (nanofluids), Int. J. Heat Mass Trans. 45 (2002) 855-863, doi: https://doi.org/10.1016/S0017-9310(01)00175-2.

4. D. Wen, Y. Ding, Experimental investigation into convective heat transfer of nanofluids at the entrance region under laminar flow conditions, Int. J. Heat Mass Trans. 47 (2004) 5181-5188, doi: https://doi.org/10.1016/j.ijheatmasstransfer.2004.07.012.

5. S. Kurajica, S. Lučić-Blagojević, Uvod u nanotehnologiju, Hrvatsko društvo kemijskih inženjera i tehnologa, Zagreb, 2017.

6. S. U. S.Choi, Z. G. Zhang, W. Yu, F. E. Lockwood, E. A. Grulke, Anomalous thermal conductivity enhancement in nanotube suspensions, Appl. Phys. Lett. 79 (2001) 2252-2254, doi: https://doi.org/10.1063/1.1408272.

7. X. Q. Wang, A. S. Mujumdar, Heat transfer characteristics of nanofluids: a review, Int. J. Therm. Sci. 46 (2007) 1-19, doi: https://doi.org/10.1016/j.ijthermalsci.2006.06.010.

8. S. S. Botha, doktorska disertacija, Synthesis and characterization of nanofluids for cooling applications, doktorska disertacija, South Africa Institute for Advance Materials Chemistry, 2007.

9. A. Asadi, S. Aberoumand, A. Moradikazerouni, F. Pourfattah, G. Żyła, P. Estellé, O. Mahian, S. Wongwises, H. M. Nguyen, A. Arabkoohsar, Recent advances in preparation methods and thermophysical properties of oil-based nanofluids: A stateof-the-art review, Powder Technol. 352 (2019) 209-226, doi: https://doi.org/10.1016/j.powtec.2019.04.054.

10. C. H. Lo, T. T. Tsung, L. C. Chen, Ni Nano-Magnetic Fluid Prepared by Submerged Arc Nano Synthesis System (SANSS), JSME Int. J. Series B 48 (2005) 750-755, doi: https://doi. org/10.1299/jsmeb.48.750.

11. T. H. Hong, H. S. Yang, C. J. Choi, Study of the enhanced thermal conductivity of Fe nanofluids, J. Appl. Phys. 97 (2005) 064311, doi: https://doi.org/10.1063/1.1861145.

12. R. Sadri, G. Ahmadi, H. Togun, M. Dahari, S. N. Kazi, E. Sadeghinezhad, N. Zubir, An experimental study on thermal conductivity and viscosity of nanofluids containing carbon nanotubes, Nanoscale Res. Lett. 9 (2014) broj članka 151, 
doi: https://doi.org/10.1186/1556-276X-9-151.

13. B. Ruan, A. M. Jacobi, Ultrasonication effects on thermal and rheological properties of carbon nanotube suspensions , Nanoscale Res. Lett. 7 (2012) broj članka 127, doi: https://doi. org/10.1186/1556-276X-7-127.

14. A. E. Aliev, M. H. Lima, E. M. Silverman, R. H. Baughman, Thermal conductivity of multi-walled carbon nanotube sheets: radiation losses and quenching of phonon modes, Nanotechnol. 21 (2010) 035709, doi: https://doi. org/10.1088/0957-4484/21/3/035709.

15. P. B. Maheshwary, C. C. Handa, K. R.Nemade, A comprehensive study of effect of concentration, particle size and particle shape on thermal conductivity of titania/water based nanofluid, Appl. Therm. Eng. 119 (2017) 79-88, doi: https:// doi.org/10.1016/j.applthermaleng.2017.03.054.

16. S. S. Sonawane, R. S. Khedkar, K. L. Wasewar, Effect of sonication time on enhancement of effective thermal conductivity of nano $\mathrm{TiO}_{2}$-water, ethylene glycol, and paraffin oil nanofluids and models comparisons, J. Experiment. Nanosci. 10 (2015) 310-322, doi: https://doi.org/10.1080/17458080 .2013.832421.

17. A. Shahsavar, M. R. Salimpour, M. Saghafian, M. B. Shafii, An experimental study on the effect of ultrasonication on thermal conductivity of ferrofluid loaded with carbon nanotubes, Thermochim. Acta 617 (2015) 102-110, doi: https:// doi.org/10.1016/j.tca.2015.08.025.

18. URL: http://www3.nd.edu/ rroeder/ame60647/slides/zeta. $\operatorname{pdf}$ (16. 3. 2015.).

19. T. X. Phuoc, M. Massoudi, R.-H. Chen, Viscosity and thermal conductivity of nanofluids containing multi-walled carbon nanotubes stabilized by chitosan, Int. J. Therm. Sci. 50 (2011) 12-18, doi: https://doi.org/10.1016/j.ijthermalsci.2010.09.008.

20. M. Hojjat, S.Gh. Etemad, R. Bagheri, J. Thibault, Thermal conductivity of non-Newtonian nanofluids: experimental data and modeling using neural network, Int. J. Heat Mass Trans. 54 (2011) 1017-1023, doi: https://doi.org/10.1016/j. ijheatmasstransfer.2010.11.039.

21. Y. Xuan, Q. Li, Heat transfer enhancement of nanofluids, Int. J. Heat Fluid Flow 21 (2000) 58-64, doi: https://doi. org/10.1016/S0142-727X(99)00067-3.

22. P. Warrier, A. Teja, Effect of particle size on the thermal conductivity of nanofluids containing metallic nanoparticles, Nanoscale Res. Lett. 6 (2011) broj članka 247, doi: https:// doi.org/10.1186/1556-276X-6-247.

23. URL: http://muri.lci.kent.edu/References/NIM_Papers/stabilization of NP suspensions/2002 Shi steric stabilization. pdf (16. 3. $201 \overline{5}$.).

24. R. Dinesh, M. J. Giri Prasad, A. S. Abhishek Raaj, Thermal conductivity enhancement techniques and thermal aging of nanofluids - a review, Int. J. Mech. Prod. Eng. 3 (2015) 124-127.

25. URL: http://www.substech.com/dokuwiki/doku.php?id=surfactants (16. 3. 2015.).

26. M. J. Assael, C. F. Chen, I. Metaxa, W. A. Wakeham, Thermal Conductivity of Suspensions of Carbon Nanotubes in Water, Int. J. Thermophys. 25 (2004) 971-985, doi: https://doi. org/10.1023/B:IJOT.0000038494.22494.04.

27. H. Xie, J. Wang, T. Xi, Y. Liu, F. Ai, Dependence of the thermal conductivity of nanoparticle-fluid mixture on the base fluid, J. Mater. Sci. Lett. 21 (2002) 1469-1471, doi: https://doi. org/10.1023/A:1020060324472.

28. S. K. Das, N. Putra, P. Thiesen, W. Roetzel, Temperature De- pendence of Thermal Conductivity Enhancement for Nanofluids, J. Heat Trans. 125 (2003) 567-574, doi: https://doi. org/10.1115/1.1571080.

29. P. Keblinski, R. Prasher, J. Eapen, Thermal conductance of nanofluids: is the controversy over?, J. Nanopart. Res. 10 (2008) 1089-1097, doi: https://doi.org/10.1007/s11051007-9352-1.

30. A. Glasnović, A. Sander, Interna skripta iz kolegija Prijenos tvari i energije, FKIT, Sveučilište u Zagrebu, 2013.

31. S. P. Jang, S. U. S. Choi, Effects of Various Parameters on Nanofluid Thermal Conductivity, J. Heat Trans. 129 (2015) 617-623, doi: https://doi.org/10.1115/1.2712475.

32. E. Ziambarasa, P. Hyldgaard, Phonon Knudsen flow in nanostructured semiconductor systems, J. Appl. Phys. 99 (2006) 054303, doi: https://doi.org/10.1063/1.2175474.

33. I. M. Mahbubul, S. A. Fadhilah, R. Saidur, K. Y. Leong, M. A. Amalina, Thermophysical properties and heat transfer performance of $\mathrm{Al}_{2} \mathrm{O}_{3} / \mathrm{R}-134 \mathrm{a}$ nanorefrigerants, International J. Heat Mass Trans. 57 (2013) 100-108, doi: https://doi. org/10.1016/j.ijheatmasstransfer.2012.10.007.

34. W. Yu, S. U. S. Choi, The Role of Interfacial Layers in the Enhanced Thermal Conductivity of Nanofluids: A Renovated Maxwell Model, J. Nanopart. Res. 5 (2003) 167-171, doi: https://doi.org/10.1023/A:1024438603801.

35. J. C. Maxwell, A Treatise on Electricity and Magnetism, $2^{\text {nd }}$ Ed. Oxford University Press, Cambridge, U.K., 1904.

36. R. L. Hamilton, O. K. Crosser, Thermal conductivity of heterogeneous two-component systems, IEC Fundament. 1 (1962) 187-191, doi: https://doi.org/10.1021/i160003a005.

37. H. Xie, H. Lee, W. Youn, M. Choi, Nanofluids Containing Multiwalled Carbon Nanotubes and Their Enhanced Thermal Conductivities, J. Appl. Phys. 94 (2003) 4967-4971, doi: https://doi.org/10.1063/1.1613374.

38. J. Koo, C. Kleinstreuer, A new thermal conductivity model for nanofluids, J. Nanopart. Res. 6 (2004) 577-588, doi: https:// doi.org/10.1007/s11051-004-3170-5.

39. S. P. Jang, S. U. S. Choi, Effects of Various Parameters on Nanofluid Thermal Conductivity, J. Heat Transf. 129 (2007) 617-623, doi: https://doi.org/10.1115/1.2712475.

40. M. Bahiraei, S. Heshmatian, H. Moayedi, Artificial intelligence in the field of nanofluids: A review on applications and potential future directions, Powder Technol. 353 (2019) 276301, doi: https://doi.org/10.1016/j.powtec.2019.05.034.

41. Ž. Ujević Andrijić, Umjetne neuronske mreže, Kem. Ind. 68 (5-6) (2019) 219-220.

42. M. Hemmat Esfe, S. Wongwises, A. Naderi, A. Asadi, M.R. Safaei, H. Rostamian, M. Dahari, A. Karimipour, Thermal conductivity of $\mathrm{Cu} / \mathrm{TiO}_{2}$-water/EG hybrid nanofluid: experimental data and modeling using artificial neural network and correlation, Int. Communicat. Heat Mass Trans. 66 (2015) 100-104, doi: https://doi.org/10.1016/j.icheatmasstransfer.2015.05.014.

43. M. Hemmat Esfe, S. Saedodin, N. Sina, M. Afrand, S. Rostami, Designing an artificial neural network to predict thermal conductivity and dynamic viscosity of ferromagnetic nanofluid, Int. Communicat. Heat Mass Trans. 68 (2015) 50-57, doi: https://doi.org/10.1016/j.icheatmasstransfer.2015.06.013.

44. M. Afrand, A. Ahmadi Nadooshan, M. Hassani, H. Yarmand, M. Dahari, Predicting the viscosity of multi-walled carbon nanotubes/water nanofluid by developing an optimal artificial neural network based on experimental data, Int. Communicat. Heat Mass Trans. 77 (2016) 49-53, doi: https://doi. org/10.1016/j.icheatmasstransfer.2016.07.008. 


\title{
SUMMARY
}

\section{Nanofluids as Heat Transfer Media}

\author{
Roko Blažic, Fabio Faraguna, Elvira Vidović, and Ante Jukić
}

Nanofluids have attracted the attention of the scientific community during last twenty years and the number of papers on nanofluids has increased significantly as a result. The increased thermal conductivity of the fluid due to the addition of nanoparticles is a basic feature that has raised intensive research on nanofluids. Considering a permanent urge in the industry to improve efficiency of production processes, including the cooling streams of processes, the increased thermal conductivity of cooling fluids opens the possibility of achieving that goal.

This paper provides an overview of nanofluid preparation methods and a description of parameters that affect the thermal conductivity of nanofluids. Also, the overviews of few models that describe the thermal conductivity of nanofluids as well as of possible mechanisms that contribute to the increase in thermal conductivity of nanofluids are given.

\section{Keywords}

Nanofluids, thermal conductivity, stability of nanofluids

Faculty of Chemical Engineering and Technology 